\title{
Primary Liver Lymphoma Presenting as Liver Nodules
}

\author{
João Manuel Silva ${ }^{a}$ Rita Ornelas Saraiva ${ }^{b}$ Guilherme Simões $^{b}$ \\ Catarina Araújo $^{c}$ Filipe Calinas $^{b}$ João Coimbra ${ }^{b}$ \\ a Internal Medicine Department, Centro Hospitalar Universitário Cova da Beira, Covilhã, Portugal; ${ }^{b}$ Gastroenterology

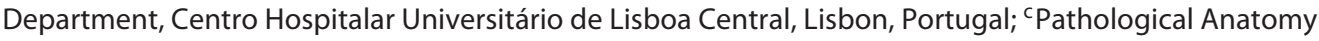 \\ Department, Centro Hospitalar Universitário de Lisboa Central, Lisbon, Portugal
}

\section{Keywords}

Liver neoplasms · Lymphoma · Diffuse large B-cell lymphoma $\cdot$ Primary lymphoma

\section{Abstract}

The liver is usually affected in advanced stages of lymphoproliferative diseases, but primary liver lymphomas (PLLs) are rare. The diagnosis is usually late, especially in patients without identifiable risk factors, with consequent worse prognosis. We report the case of a 59-year-old female with progressive worsening pain in the right hypochondrium and weight loss. She was previously healthy and had a family history of gastrointestinal and gynecologic neoplasms. During the initial investigation, three liver nodules suggestive of liver metastases were found. Nevertheless, no primary neoplasm was identified in a subsequent evaluation with imaging and endoscopic exams. Laboratory exams excluded hepatic infections, metabolic diseases, and acquired immunosuppression. Biopsy of the lesions revealed diffuse large B-cell lymphoma. Lymph node and medullar involvement were excluded, and the diagnosis of PLL was assumed. The patient started chemotherapy with R-CHOP. With this case, we intend to alert for this differential diagnosis of liver nodules, even in the absence of predisposing conditions for lymphoma. We point out the need to define universal diagnosis criteria for this pathology.

(c) 2020 Sociedade Portuguesa de Gastrenterologia Published by S. Karger AG, Basel

\section{Apresentação nodular de Linfoma hepático primário}

\section{Palavras Chave}

Neoplasia hepática $\cdot$ Linfoma $\cdot$ Linfoma B Difuso de Grandes Células · Linfoma Primário

\section{Resumo}

O fígado é geralmente afetado em estádios avançados de doenças linfoproliferativas, mas os linfomas primários do fígado são raros. O diagnóstico é habitualmente tardio, principalmente em doente sem fatores de risco identificados, e consequentemente com pior prognóstico. Apresentamos o caso de uma doente de 59 anos, com quadro álgico de intensidade crescente no hipocôndrio direito e perda ponderal. A doente era previamente saudável e tinha história familiar de neoplasia gastrointestinal e karger@karger.com www.karger.com/pjg

Karger $\stackrel{\text { ' }}{5}$

BOPEN ACCESS
(C) 2020 Sociedade Portuguesa de Gastrenterologia Published by S. Karger AG, Basel

This article is licensed under the Creative Commons AttributionNonCommercial-NoDerivatives 4.0 International License (CC BYNC-ND) (http://www.karger.com/Services/OpenAccessLicense). Usage and distribution for commercial purposes as well as any distribution of modified material requires written permission.
João Manuel Silva

Internal Medicine Department

Centro Hospitalar Universitário Cova da Beira

Alameda Pêro da Covilhã, PT-6200-251 Covilhã (Portugal)

joaomsilva71@gmail.com 
ginecológica. No estudo inicial, foram identificadas três imagens nodulares hepáticas sugestivas de metástases. No entanto, não se identificou tumor primário em exames de imagem nem endoscópicos. Foram também excluídas infeções hepáticas, doença metabólica e imunossupressão adquirida. A biópsia das lesões hepáticas revelou tratar-se de linfoma B difuso de grandes células. Foi excluído envolvimento ganglionar e medular pelo que se assumiu o diagnóstico de Linfoma Primário do Fígado. A doente iniciou quimioterapia com R-CHOP. Com este caso pretendemos alertar para a necessidade de equacionar este diagnóstico diferencial de nódulos hepáticos, mesmo na ausência de fatores de risco para linfoma. Também alertamos para a necessidade de se definirem critérios diagnósticos universais para esta patologia.

(C) 2020 Sociedade Portuguesa de Gastrenterologia Publicado por S. Karger AG, Basel

\section{Introduction}

Liver involvement is frequent in advanced systemic hematologic disease [1-3] (10\% of non-Hodgkin's lymphomas) [4], but primary liver lymphomas (PLLs) are rare [5]. The diagnosis is usually late, and prognosis is poor [5]. Earlier diagnosis is associated with better survival [6], and therefore this condition should be considered in the approach of a patient with liver disease. We present a case of a patient with PLL with multiple nodular lesions.

\section{Case Report}

We present the case of a 59-year-old female evaluated for abdominal pain in the right hypochondrium, persistent for 1 month and a half. The pain had a sudden onset and was progressively worsening, and aggravated with deep inspiration. The patient also referred progressive tiredness, weight loss (not quantified) and night sweats, without fever. Personal history included asthma and seafood atopy. A family history of gynecologic (breast and uterus) and gastrointestinal (stomach, intestine, hepatocellular carcinoma) neoplasms was also recorded. The patient denied exposure to ionizing radiation or chemicals, recent travelling prior to the onset of symptoms, drinking unsafe water, or ingesting untreated dairy products. One year before, she underwent upper gastrointestinal endoscopy and abdominal ultrasound for dyspepsia, as well as total colonoscopy for colorectal cancer screening, both exams were normal. Blood analysis performed at that time showed no alteration. She was initially medicated with analgesics with incomplete symptomatic relief.

The blood analysis revealed normocytic anemia without other changes in blood count, and cytocholestasis without hyperbilirubinemia (Table 1). Tumor markers (alpha-fetoprotein, CEA, CA19.9), hepatotropic virus serology (HBV, HCV, HIV, EBV), and the liver autoimmunity study were all negative.

Primary Liver Lymphoma

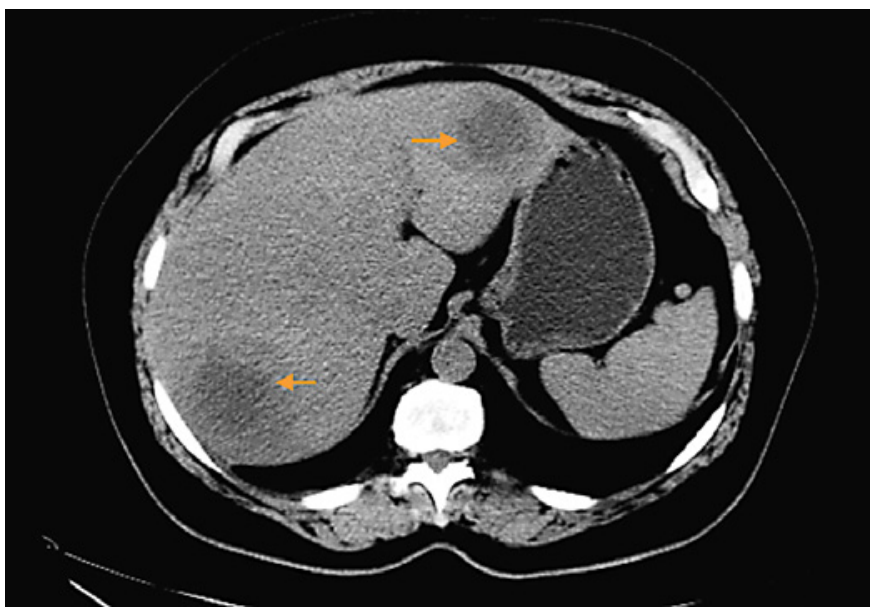

Fig. 1. Abdominal CT showing two liver lesions (highlighted by arrows).

An abdominal and pelvic ultrasound was performed, which revealed three solid nodules in the liver. These were first characterized by computed tomography (CT) scan and then by magnetic resonance imaging (MRI): two in the right lobe (segment VII and $\mathrm{V})$, both with about $6 \mathrm{~cm}$, and one in the left lobe, with about 4.5 $\mathrm{cm}$, all of them with restricted diffusion and central necrosis suggestive of secondary deposits, in a liver without stigmas of chronic liver disease. Adenomegalies and splenomegaly were excluded.

Subsequent thoracic, abdominal, and pelvic CT scan (Fig. 1) excluded other lesions, including primary lesions suggestive of neoplastic disease. A positron emission tomography scan (PET scan) was not performed. A CT-guided biopsy of the liver lesions was made, revealing a diffuse large germinal center B-cell-like lymphoma expressing CD10+, blc-6, and MUM1, without rearrangement of the MYC and BCL2 genes (Fig. 2).

Medullary involvement was excluded with bone biopsy, and therefore the diagnosis of primary hepatic lymphoma was assumed. At the time, the patient was slightly symptomatic, but still capable of performing daily activities without help (ECOG Performance Status 1).

The patient is undergoing chemotherapy with rituximab, cyclophosphamide, doxorubicin, vincristine and prednisolone ( $\mathrm{R}$ $\mathrm{CHOP}$ ), and has already received 4 cycles, with good tolerance.

\section{Discussion/Conclusion}

PLL is a rare entity due to the lack of abundant lymphoid tissue in the normal liver [7]. It corresponds to $0.4 \%$ of extranodal lymphomas and $0.016 \%$ of non-Hodgkin's lymphomas $[5,8]$. It most commonly affects male patients $(2: 1)$ aged between 50 and 62 years $[2,8,9]$. Usually, primary lymphomas develop in patients with previous liver disease: association with viral infection $(\mathrm{HCV}$, HBV, EBV, HIV), autoimmune diseases, immunosup- 
Table 1. Relevant laboratory analysis

\begin{tabular}{|c|c|c|c|}
\hline Laboratory parameter & & Value/unit & Reference range \\
\hline \multirow[t]{11}{*}{ Complete blood count } & Hemoglobin & $11.0 \times 10 \mathrm{~g} / \mathrm{L}$ & $12.0-15.0$ \\
\hline & Median globulin volume & $86 \mathrm{fL}$ & $78.0-96.0$ \\
\hline & Median hemoglobin volume & $27.9 \mathrm{pg}$ & $26.0-33.0$ \\
\hline & Leucocytes & $8.33 \times 10^{9} / \mathrm{L}$ & $4.5-11.0$ \\
\hline & Neutrophils & $4.84 \times 10^{9} / \mathrm{L}$ & $2.0-8.5$ \\
\hline & Eosinophils & $0.1 \times 10^{9} / \mathrm{L}$ & $0.0-0.6$ \\
\hline & Basophils & $0.02 \times 10^{9} / \mathrm{L}$ & $0.0-0.1$ \\
\hline & Lymphocytes & $2.35 \times 10^{9} / \mathrm{L}$ & $0.9-3.5$ \\
\hline & Monocytes & $1.02 \times 10^{9} / \mathrm{L}$ & $0.2-1.0$ \\
\hline & Platelet count & $429 \times 10^{9} / \mathrm{L}$ & $150-450$ \\
\hline & Sedimentation rate & $69 \mathrm{~mm} / \mathrm{h}$ & $<20$ \\
\hline Coagulation & INR & 1.31 & $0.8-1.2$ \\
\hline \multirow[t]{15}{*}{ Biochemistry } & Aspartate aminotransferase & $54 \mathrm{U} / \mathrm{L}$ & $5.0-34.0$ \\
\hline & Alanine aminotransferase & $48 \mathrm{U} / \mathrm{L}$ & $0.0-55.0\left(<20^{*}\right)$ \\
\hline & Gamma-glutamyltransferase & $238 \mathrm{U} / \mathrm{L}$ & $9-36$ \\
\hline & Alkaline phosphatase & $256 \mathrm{U} / \mathrm{L}$ & $40-150$ \\
\hline & Lactate dehydrogenase & $442 \mathrm{U} / \mathrm{L}$ & $125-220$ \\
\hline & Total bilirubin & $0.40 \mathrm{mg} / \mathrm{dL}$ & $0.20-1.20$ \\
\hline & Total albumin & $38.3 \mathrm{~g} / \mathrm{L}$ & $32.0-46.0$ \\
\hline & C-reactive protein & $114.8 \mathrm{mg} / \mathrm{L}$ & $<5.0$ \\
\hline & Glucose & $76 \mathrm{mg} / \mathrm{dL}$ & $60-100$ \\
\hline & Urea & $42 \mathrm{mg} / \mathrm{dL}$ & $21.0-43.0$ \\
\hline & Creatinine & $0.74 \mathrm{mg} / \mathrm{dL}$ & $0.57-1.11$ \\
\hline & Sodium & $142 \mathrm{mEq} / \mathrm{L}$ & $136-145$ \\
\hline & Potassium & $4.4 \mathrm{mEq} / \mathrm{L}$ & $3.5-5.1$ \\
\hline & Chloride & $104 \mathrm{mEq} / \mathrm{L}$ & $98-107$ \\
\hline & Calcium & $9.5 \mathrm{mg} / \mathrm{dL}$ & $8.4-10.20$ \\
\hline
\end{tabular}

Major changes are shown in bold. * Upper limit of normal according to the World Gastroenterology Organization [11].

pression $[2,10]$, liver cirrhosis $[7,9]$, and exposure to chemicals [8] were described.

Clinical manifestations of PLL are nonspecific. In most cases, the main complaint is abdominal discomfort due to liver distension [11]. Classical B symptoms (fever, weight loss, night sweats) are usually present (up to $85 \%$ ), but may be absent [7].

The blood analysis commonly reveals altered liver biochemistry, particularly cholestasis due to the hepatic infiltration (present in up to $70 \%$ of cases) [6]. Alpha-fetoprotein and CEA values are normal in most cases and may help in the differential diagnosis $[4,9]$.

Most cases of PLL present with nodular solid lesions, either single (33-60\%) or multiple (33-50\%) [4, 12-14]. These present an expansive and destructive pattern in CT and MRI. Therefore, they are often confused with metastatic lesions $[2,6,13,15]$. Diffuse infiltrative lesions are rare $[1,6]$ and, when present, usually invade portal tracts and sinusoids [6]. This pattern is rare in Caucasians [4] and more common in Chinese patients $[4,16]$.

Histologic diagnosis is done by biopsy of the lesion, which shows lymphoma infiltration. Non-Hodgkin B-cell lymphoma is the most frequent, followed by T-cell lymphomas. Overall, the most common histologic result is diffuse large B-cell lymphoma (DLBCL), a subtype of nonHodgkin B-cell lymphoma $[2,4,7,8,10]$. This is an aggressive lymphoma, associated with rapid growth. DLBCL may be classified according to Hans et al. [17] by immunohistochemical stain expression as germinal center Bcell-like and non-germinal center B-cell-like. The germinal center B-cell-like profile (CD10+, blc-6, and MUM1), as in this case, yields a better prognosis [17]. The absence of documented MYC and BCL2 mutations allowed the classification of the lymphoma as a double-expressor. 
Fig. 2. a Large and blue cell hepatic infiltration whose immunohistochemical profile is: $\mathrm{CD} 20(+), \mathrm{CD} 3(-), \mathrm{CD} 5(-), \mathrm{CD} 10(+)$, BCL2 (+) heterogeneous labelling, BCL6(+), MUM1(-), Cyclin D1(-), MYC(+). The Ki67 expression is $70 \%$. HE $400 \times$. b Immunohistochemical stain CD20(+) in tumoral liver specimen. HE 200x.

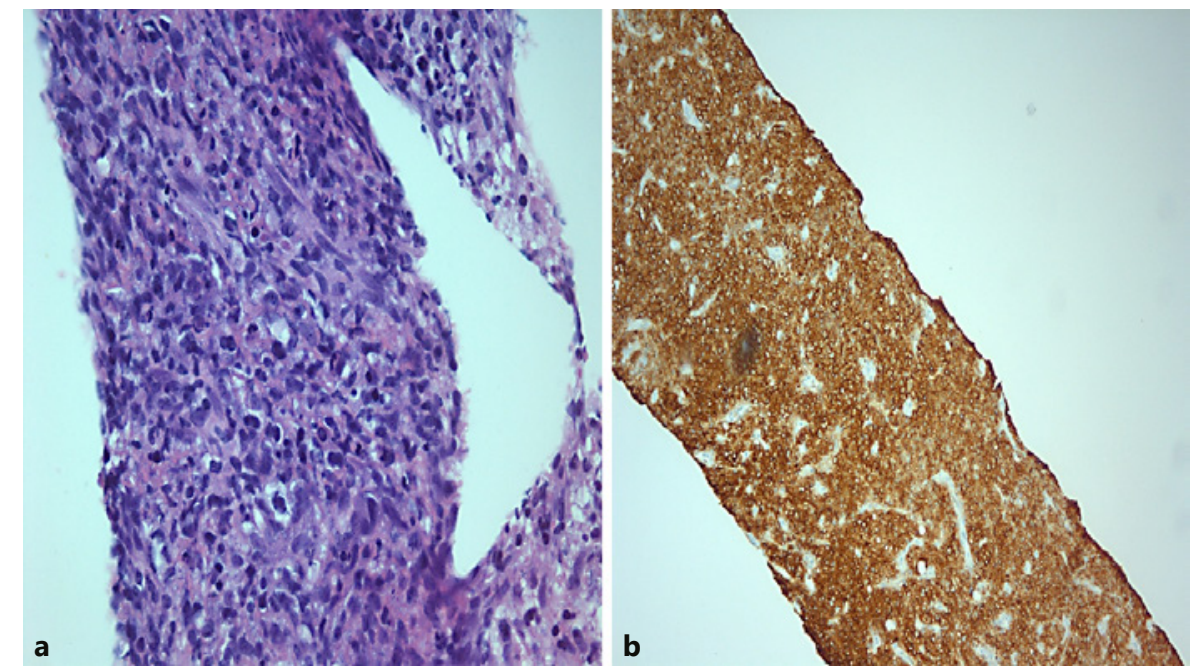

There are some PLL reported in the literature, generally diagnosed on the basis of nonuniform criteria, as there are no consensually accepted diagnostic criteria.

Caccamo et al. [18] considers PLL a lymphoma limited to the liver, whose symptoms should be explainable exclusively by liver involvement, without evidence of extrahepatic localization (superficial lymphadenopathy, splenomegaly, abnormal hematological parameters, spleen, or bone marrow) over a period of at least 6 months after appearance of the hepatic lesions. These criteria were proposed in 1986 based on a patient with Kaposi sarcoma and with gastric mucosa and abdominal lymph node affection [19].

In 1995, Lei et al. [11] proposed that the diagnosis of PLL should be made by the cumulative presence of symptoms caused mainly by liver involvement at the time of presentation, absence of distant lymphadenopathy (palpable clinically at presentation or detected during staging radiologic studies), and the absence of a leukemic blood picture in the peripheral blood film. More recently, in 2001, Emile et al. [3] adopted the criteria Lei et al. [11], but added that presence of lymphomatous infiltration of the hepatic hilum, spleen, or bone marrow at the time of diagnosis should not exclude the diagnosis of PLL.

Due to the lack of uniform diagnosis criteria, some published case reports might correspond to metastatic hepatic lymphoma instead of real primary lymphoma. Also, the criteria proposed by Caccamo et al. [18] might lead to a delay of 6 months to establish the diagnosis, with prognostic implications.

In this case report, the diagnosis of PLL was based on the exclusive liver involvement with documented absence of extrahepatic involvement (lymphadenopathy, splenomegaly, and secondary lesions) $[1,11]$.

Some authors excluded the presence of extrahepatic disease by CT scan [4, 9], whereas others used FDG-PET [10], since it has a higher sensitivity for the diagnosis of extrahepatic lesions [19]. Ugurluer et al. [8], in a series of 41 patients diagnosed with primary liver disease between 1977 and 2014, showed that $63.4 \%$ underwent CT scan and $56.1 \%$ ultrasound, whereas a PET scan was performed in only $14.6 \%$ of the patients. Although we agree that FDG-PET scan would have been the best exam for diagnosis and staging, it was not readily available and therefore was not performed, as postponing the initiation of chemotherapy would have prognostic consequences.

Evidence on the optimal therapy for PLL is very scarce [8]. The most commonly used regimens involve R-CHOP [7] which is the first-line chemotherapy for germinal center type non double-hit DLBCL in advanced Ann Arbor stage (III-IV).

Survival may exceed 13 years, with average diseasefree survivals of $69 \%$ at 5 years and $56 \%$ at 10 years [8], but varies greatly according to the stage of disease at diagnosis (early diagnoses are associated with better prognosis) [6].

Central nervous system (CNS) affection in DLBCL is rare, and the decision for prophylactic chemotherapy should be individualized [20]. In this case, according to the Central Nervous System-International Prognostic Index (CNS-IPI) score, the patient had an intermediate risk (3.4\%) of recurring in the CNS [21], and therefore no prophylactic CNS chemotherapy was performed. 
In conclusion, the diagnosis of PLL should be considered in the differential diagnosis of hepatic nodular lesions, even in patients without identified predisposing conditions. Its diagnosis requires high clinical suspicion and is established histologically. Given the rarity of the disease, it is important to define universal, consensual diagnostic criteria, which would allow diagnostic standardization and thus a better clinical knowledge of the entity and its response to different possible therapeutic regimens.

\section{Statement of Ethics}

Ethical and legal principles were followed according to the Declaration of Helsinki. Written consent was obtained from the patient.

\section{Disclosure Statement}

The authors have no conflicts of interest to declare.

\section{Funding Sources}

The authors received no external funding.

\section{Author Contributions}

J.M.S. was part of the assistant medical team, designed, and wrote the article. R.S., G.S., F.C., and J.C. were part of the assistant medical team and reviewed the manuscript. C.A. contributed with anatomopathological images and review of the manuscript. All authors approved the final version to be published.

\section{References}

1 Lei KI. Primary non-Hodgkin's lymphoma of the liver. Leuk Lymphoma. 1998 Apr;29(3-4): 293-9.

2 Choi WT, Gill RM. Hepatic Lymphoma Diagnosis. Surg Pathol Clin. Elsevier Inc; 2018 JUn;11(2):389-402.https://doi.org/10.1016/j. path.2018.02.003.

3 Emile JF, Azoulay D, Gornet JM, Lopes G, Delvart V, Samuel D, et al. Primary nonHodgkin's lymphomas of the liver with nodular and diffuse infiltration patterns have different prognoses. Ann Oncol. 2001 Jul;12(7): 1005-10.

4 Agmon-Levin N, Berger I, Shtalrid M, Schlanger H, Sthoeger ZM. Primary hepatic lymphoma: a case report and review of the literature. Age Ageing. 2004 Nov;33(6):637-40

5 Elreda L. A Unique Case of Primary Hepatic CD30-Positive, CD15-Negative Classical Hodgkin's Lymphoma Presenting as Fever of Unknown Origin and Acute Hepatic Failure. Haematol Int J. 2018;2(3).

6 Abe H, Kamimura K, Kawai H, Kamimura H, Domori K, Kobayashi Y, et al. Diagnostic imaging of hepatic lymphoma. Clin Res Hepatol Gastroenterol. 2015 Sep;39(4):435-42.

7 Laroia ST, Rastogi A, Panda D, Sarin SK. Primary Hepatic Non-Hodgkin's Lymphoma: An Enigma Beyond the Liver, a Case Report. World J Oncol. 2015 Apr;6(2):338-44.
8 Ugurluer G, Miller RC, Li Y, Thariat J, Ghadjar P, Schick U, et al. Primary hepatic lymphoma: A retrospective, multicenter rare cancer network study. Rare Tumors. 2016 Oct; 8(3):6502

9 Myoteri D, Dellaportas D, Arkoumani E, Marinis A, Zizi-Sermpetzoglou A. Primary hepatic lymphoma: a challenging diagnosis. Case Rep Oncol Med. 2014;2014:212598.

10 Khalid S, Zaheer S, Khalid M, Zaheer S, Alam MS. Primary liver lymphoma. JBR-BTR. 2013 Mar-Apr;96(2):84-6.

11 Lei KI, Chow JH, Johnson PJ. Aggressive primary hepatic lymphoma in Chinese patients. Presentation, pathologic features, and outcome. Cancer. 1995 Oct;76(8):1336-43.

12 Steller EJ, van Leeuwen MS, van Hillegersberg R, Schipper ME, Rinkes IH, Molenaar IQ. Primary lymphoma of the liver - A complex diagnosis. World J Radiol. 2012 Feb;4(2):53-7.

13 Noronha V, Shafi NQ, Obando JA, Kummar S. Primary non-Hodgkin's lymphoma of the liver. Crit Rev Oncol Hematol. 2005 Mar; 53(3):199-207.

14 Page $\mathrm{RD}$, Romaguera JE, Osborne $\mathrm{B}, \mathrm{Me}$ deiros LJ, Rodriguez J, North L, et al. Primary hepatic lymphoma: favorable outcome after combination chemotherapy. Cancer. 2001 Oct;92(8):2023-9.
15 Santos ES, Raez LE, Salvatierra J, Morgensztern D, Shanmugan N, Neff GW. Primary hepatic non-Hodgkin's lymphomas: case report and review of the literature. Am J Gastroenterol. 2003 Dec;98(12):2789-93.

16 Haider FS, Smith R, Khan S. Primary hepatic lymphoma presenting as fulminant hepatic failure with hyperferritinemia: A case report. J Med Case Rep. 2008 Aug;2:279.

17 Hans CP, Weisenburger DD, Greiner TC, Gascoyne RD, Delabie J, Ott G, et al. Confirmation of the molecular classification of diffuse large B-cell lymphoma by immunohistochemistry using a tissue microarray [Internet]. Blood. 2004 Jan;103(1):275-82.

18 Caccamo D, Pervez NK, Marchevsky A. Primary lymphoma of the liver in the acquired immunodeficiency syndrome. Arch Pathol Lab Med. 1986;110(6):553-5.

19 Xiong F, Guan Y. Primary hepatic lymphoma: is it a disease entity? Hepatoma Res. 2017; 3(5):73.

20 Qualls D, Abramson JS. Advances in risk assessment and prophylaxis for central nervous system relapse in diffuse large B-cell lymphoma. Haematologica. 2019 Jan;104(1):25-34.

21 Schmitz N, Zeynalova S, Nickelsen M, Kansara R, Villa D, Sehn LH, et al. CNS International Prognostic Index: A risk model for CNS relapse in patients with diffuse large B-Cell lymphoma treated with R-CHOP. J Clin Oncol. 2016 Sep;34(26):3150-6. 